\title{
The Effects of Physical Resources on the Implementation of Inclusive Education In Public Secondary Schools - Kenya
}

\author{
${ }^{1}$ Bibiana Ruguru Ireri (Sr.), ${ }^{2}$ Dr. Madrine King'endo, ${ }^{3}$ Prof. Simon Thuranira: \\ ${ }^{1,2,3}$ Department of Education, Communication, Administration and Planning
}

\begin{abstract}
Educational frameworks and Kenyan constitutions mandate schools to adopt; design and implement programmes that support inclusive education. Despite the inclusive education policy, disability remains a major course of exclusion in public secondary schools in Kenya. The study evaluated the influence physical resources towards the implementation of inclusive education in Kenyan schools. The study employed mixed method research design which uses both qualitative and quantitative methods. Purposive sampling technique was used to select 201 respondents from 18 extra-county and county public secondary schools that had enrolled learners with physical disabilities. Quantitative data was collected using questionnaires while qualitative data was collected through interviews and focus group discussions. A t-test was used to test the significance and determine whether to reject or accept the study hypotheses. An analysis of the findings indicated significant relationships between physical resources and implementation of inclusive education. The Linear Model showed a moderate positive correlation between human resource and inclusion. The model further showed that the rate of physical resource accounted for some variation towards the implementation of inclusive education. Creating an inclusive school where physical resources are modified and restructured to respond to learner diversity is a complex process with many inter-related elements. The schools should have a collaborative approach by creating back-up partnerships with parents, the community and disability associations. There is a need to mobilize all key stakeholders to modify physical resources in order to overcome barriers that hinder access and participation for all learners
\end{abstract}

Keywords: Policy; Inclusive Education; Practices; Schools

\subsection{Introduction}

Building inclusive schools remains one of the biggest challenges facing education system worldwide (Mitchell, 2015). Inclusion remains a complex and contentious issue as the development of inclusive practices in schools is not well understood (Ainscow, 2005; Anastasiou \& Kauffman, 2012; Winzer \& Mazurek, 2017). Inclusive education affects not just in principle and the nature of education provided for students with special education needs, but it calls into questioning the broader aims of education, the purpose of schools, the nature of the curriculum, approaches to assessment, and schools' accommodation to diversity. The way in which regular schools respond to students with disability can be a measure of quality education for all students (UNESCO, 2015). Weber and Ruch (2012) argue that a good school is good for all students and work for the achievement of all learners. However, there are practices related to school systems and individuals that work against the development of good inclusive practices. Effective modification of physical resources can create an inclusive environment that can give every learner fair access and participation to education. This calls for a need to modify the physical resources and the environment to accommodate learner diversity (Rickert, 2010; Agarwal \& Chakravarti, 2014).

The concept of inclusive education dates back to the $20^{\text {th }}$ century, with many countries striving to adopt and develop education for learners with physically challenges. The movement towards inclusive education for learners with special learning needs began in the 1960s (Forlin, 2005). The United Nations has made influential declarations regarding inclusive education, such as the Convention against Discrimination in 
Education (1960) that mandated persons with disability to access education without discrimination. The declaration on the Rights of Disabled Persons (1975), guaranteed the respect and dignity of the persons living with disability and the Convention on the Rights of the Child (1989), endorsed the right of every child. Similarly, the World Conference of 1990 (Jomtien Declaration) in Thailand, set goals of Education for All (EFA), which was reaffirmed in the Dakar Framework of 2000 in Senegal. Subsequently, the Salamanca Statement and Framework of Action on Special Needs Education in Spain (UNESCO, 1994), adopted the principle of inclusion and provided a major impetus for inclusive education. The Salamanca Statement is arguably the most significant international document in the field of special education (Budlender, 2015). The major recommendation of Salamanca Statement was that every child with special learning needs has a right to access education in the neighbourhood school. The governments were required to give priority on their policy, legal and budgetary provision to restructure the education system to cater for learner diversity (UNESCO, 2015)

Subsequently, there has been considerable efforts by many nations to work on their educational policies and practices towards inclusive education, although questions arise on its efficacy and efficiency (Kalyanpur, 2014; Mukhopadhyay, 2015). While several countries' legislations and policies appear to be committed to inclusive education, practices in schools may not meet this rhetoric (Mitchell, 2005). The evidence underpinning inclusive education in African countries is weak and fragmented (Howgego, Miles \& Myers, 2014). Inclusion is marred by inaccessible environments, lack of reasonable accommodation, negative attitudes, discriminatory application and admission procedures, lack of disability policies and choices, disadvantage students with disabilities in Africa (Chataika, Mckenzie, Swart \& Cleophas, 2012). Despite the fact that Nigeria enacted inclusive education policy in 2008, it experiences socio-economic barriers and a lack of teacher preparedness on inclusive practices, which is compounded by administrative problems within schools (Igbokwe, Mezieobi \& Eke, 2014). Similarly, inclusive education in Ugandan experiences major hitches which include negative cultural attitudes towards disability, poor funding, and inadequate teacher training in inclusive practices and lack of mobility devices, which discourage resource allocation to learning institutions (Abimanyi \& Mannan, 2014).

Kenya is among the African countries that has made remarkable advances in the pursuit for inclusive education (Nungu, 2014). The government has embraced and supported the practice of inclusive education by domesticating various international agreements in its laws (Njoka et al., 2012). The policy framework (Republic of Kenya, 2012), recommended that all secondary schools adopt, design and implement programs that implement inclusive education. In spite of inclusive education policy, disability remains a major course of exclusion in schools. According to Doyle \& Giangrec (2013), successful implementation of inclusive educational programs requires the involvement and the support from all the stakeholders. The Kenyan Basic Education Act of 2017 mandates that BOM should be adequately committed as their role is crucial in the implementation of educational programs including inclusive education policy. Therefore the study evaluated the effects of physical resources towards the implementation of inclusive education in public secondary schools in Kenya

\subsection{Research Objective}

To determine the effects of physical resources towards the implementation of inclusive education in public secondary schools

\subsection{Null Hypotheses of the Study}

There is no significant relationship between physical resources and the implementation of inclusive education

\subsection{Justification of the Study}

The Kenyan government has made some progress towards meeting obligations under its laws as well as endorsing and domesticating various international policies to support inclusive education (Njoka et al., 2012). Remarkably, the constitution of Kenya (Republic of Kenya, 2010) embraces a bold rights-based approach to education, which provides for the right of all learners to free and compulsory basic education. However, despite Kenya's international commitment to realize the right to education for learners with 
disabilities, few studies have been done in secondary schools in Kenya and in particular, no study has been conducted to evaluate the effectiveness of secondary schools on the implementation of inclusive education policy. Literature on Kenya regarding policy-to-practice is scarce. Therefore, this study contributed towards the knowledge production and transfer through investigation and analysis of the practices of policy in relation to the implementation of inclusive education in a school context

\subsection{Literature Review}

Transforming school vision into practice requires physical accessibility to school buildings for students with disabilities (Stubbs, 2008). A school environment that is inaccessible to students in wheelchairs or to those with other mobility aides and need elevators, ramps, paved pathways and lifts to get in and around buildings limit the number of learners with physical disabilities get enrolled in a school. Provision of resources is vital for the success of special needs education services. Unfortunately, the limitation of resources remains a barrier in many schools in developing countries, (Villac, 2016). Obtaining appropriate equipment as needed for individual students e.g. adapted mobility devices and walking frames for students, is a continuing barrier to providing equal access to education all through the school system (Dalton, 2005). More emphasis though is placed on assessment and evaluation systems which focus on academic performance rather than individual progress discriminating against learners with special education needs. Therefore, it is advisable to intensify activities to ensure resource allocation and modification that cater for learner diversity in schools

Both research and best practices have shown the need for establishing and accessing enabling physical resources to accommodate learners with disabilities. Unless the physical environment is accessible to students with physical disabilities, physical resources become barriers to access and participation. In order to make buildings welcoming, comfortable, accessible, attractive and functional, special attention should be given to the design and development of entrances and routes of travel, furniture and fixtures, (Burgstahler, 2009). Accessibility can go beyond passageways, stairs, and ramps to recreational areas, paved pathways, and door handles. A student with cerebral palsy, for instance, may not have the ability to hold and turn a traditional handle. Classrooms must be able to accommodate a student's assistive technology devices, as well as other furniture to meet individual needs (EENET, 2003).

\subsection{The Social Model of Disability}

Social model of disability recognizes that all learners have diverse needs and at the same time have equal rights to access and participate in all spheres in the society including education system. It recognizes that social perceptions, attitudes, institutions and policies all can be modified to respond to learner diversity and access to equal opportunities of disabled people (Ahmad, 2015). Cook and Polgar (2015) argue that the school contextual components that include physical, social, cultural and institutional mechanisms have been designed to cater for the education of able-bodied learners. The buildings, highly structured curriculum, teachers and the environmental background, were structured and prepared to handle non-disabled learners. The school beliefs, rituals and values that give the school its identity were socially constructed. These values and beliefs are highly upheld and easily influence the school activities and perceptions which influence the behaviour of its members towards learners with special education needs (Hendricks, 2016).

The concepts of structures, systems, and practices are dominant in the social theory of disability. These school systems and practices can perfectly facilitate learners with disabilities to participate fully in the learning process. However, when the systems are not modified and restructured to provide an enabling environment, they become disabling to learners with disabilities. Among the practices of policy are physical resources, which, if not modified can pose as real barriers to the implementation of inclusive education. The social model of disability propagates that any barrier that hinders learners from accessing and participating in the learning process is really disabling. Schools are best avenues that can demonstrate implementation of inclusive education. This can be implemented by removing all disabling physical barriers, to enable learners with disabilities to thrive and exploit every opportunity. This way, the school provides high quality education to all, view differences as a resource and responds constructively to the special needs of all learners. Similarly, such a school ensures that inclusive education practices are embedded in their vision, mission and initiatives 


\subsection{Methodology of the Research}

The study employed mixed methods research designs, in order to analyze the effects of physical resources towards the implementation of inclusive education in schools (Johnson and Onwuegbuzie, 2007; McMillan \& Schumacher 2006). Quantitative data enabled the study to apply statistical tests and derive important facts on the influence of physical resources in order to make informed conclusion. Qualitative data enabled the study to obtain data from the real experience of what students with disabilities go through during the learning process

\subsection{Sampling Procedures and Sample Size}

The population of the study included 42 county and extra-county schools. Purposive sampling was used to select 18 schools that had enrolled learners with physical disabilities. A sample consisting of 201 respondents comprised of teachers, non-disabled students and learners with physical challenges. The study used questionnaires for all the teachers, interview guides for learners with physical disabilities and focus group discussions for non-disabled students

\subsection{Validity and Reliability}

The instruments were reviewed by the researcher's supervisors at the university, who validated the instruments (Gall, Gall, \& Borg, 2007). A Cronbach's coefficient alpha technique was used to determine internal consistency of the items. In the study, the items were considered reliable if they produced a reliability coefficient of 0.70 and above (Cohen \& Swerdlik, 2005). The reliability coefficient of the influence of physical resources towards the implementation of inclusive education from the questionnaires was 0.708

\subsection{Data Collection}

The researcher obtained written permission from the National Council of Science, Technology and Innovation (NACOSTI) Nairobi. The questionnaires were delivered, filled and collected from 100 teachers; interviews were conducted from 11 physically challenged learners and 90 non-disabled students participated in 9 focus groups

\subsection{Quantitative and Qualitative Data Analysis}

Descriptive statistics tables were used to analyze quantitative data by use of frequencies and percentages. Hypothesis testing was carried out via the Analysis of Variance (ANOVA) and t-tests. The data was analyzed using the Statistical Package for Social Sciences (SPSS) version 20. All the interviews and focus group discussions were transcribed and organized into meaningful categories, grouped them into codes and organized data into themes, which were presented in a narrative form (Frankfort-Nachmias \& Nachmias, 2008).

\subsection{Ethical Issues}

Before the administration of the research instruments, the author obtained a research approval from an Ethics Review Committee, from Pwani University an accredited organization by the National Commission for Science, Technology and Innovation (NACOSTI, KENYA) and a certificate of approval was obtained

\section{Results and Discussions \\ 4.0 Introduction}

The research findings were organized according to the responses derived from the questionnaires, interviews and focus group discussions. The researcher visited 18 county and extra-county schools and gave out 120 questionnaires to the teachers, of which $100(83.3 \%)$ questionnaires were fully filled and returned.

\subsection{Teachers Training on Special Education}

The data on teachers' qualification on special needs education is represented on Table 2 
Table 1: Teachers' Additional Training and Qualification on Special Needs Education

\begin{tabular}{|l|r|r|}
\hline Special education training & Frequency & Percentage \\
\hline Short courses & 11 & $11 \%$ \\
\hline In-service Training & 5 & $5 \%$ \\
\hline Diploma & 3 & $3 \%$ \\
\hline Degree & 0 & $0 \%$ \\
\hline Masters & 0 & $0 \%$ \\
\hline Other Qualifications & 0 & $0 \%$ \\
\hline None & 81 & $81 \%$ \\
\hline Total & 100 & $100 \%$ \\
\hline
\end{tabular}

The results in Table 1, shows that the majority of teachers $(81 \%)$ have not been trained in any special needs education apart from the teacher's professional qualification, while $11 \%$ had short courses on special education. A small proportion of 5\% and 3\% respectively had in-service and diploma certificates. This implies that the greatest number of teachers lack skills in special education needs. To confirm this, Wachira (2012), asserts that factors' influencing the implementation of inclusive education policy in Kenya was largely lack of the skills and knowledge on special education needs.

\subsection{Physically Challenged Learners Enrolled Schools}

The study sought to establish the number of physically challenged students who had been registered in secondary schools. The information was represented in Tables 2 and 3

Table 2: Teachers report on learners with physical challenges currently enrolled in the school

\begin{tabular}{|l|l|l|}
\hline Number of physically challenged & Frequency & Percentage \\
\hline $1-2$ & 70 & 70 \\
\hline $3-5$ & 16 & 16 \\
\hline None & 14 & 14 \\
\hline Total & $\mathbf{1 0 0}$ & $\mathbf{1 0 0}$ \\
\hline
\end{tabular}

Table 3: Teachers report on learners with physical challenges previously enrolled in the school

\begin{tabular}{|l|l|l|}
\hline No. of PC enrolled in the past in the schools & Frequency & Percentage \\
\hline $1-5$ & 59 & 59.0 \\
\hline $6-10$ & 5 & 5.0 \\
\hline $10+$ & 4 & 4.0 \\
\hline None & 32 & 32.0 \\
\hline Total & 100 & 100.0 \\
\hline
\end{tabular}

The results in Table 2 shows that majority of teachers $(70 \%)$ indicated that schools previously admitted between 1 and 2 learners with disabilities. Further, 16\% of participants reported between 3 and 5 students while $14 \%$ did not have learners with physical challenges. This report implies that schools have very few learners with physical disabilities enrolled in their schools

Majority (59\%) of the teachers in Table 3 revealed that several schools previously had enrolled between 1 and 5 learners with disabilities, while, 5\% indicated to have between 6 and 10 students and $4 \%$ revealed to have admitted more than 10 such students. A significant number of teachers (32\%) indicated that several schools had never admitted learners with disabilities. This information was crucial because the study could only have been possible when there were schools who had currently or previously admitted learners with disabilities

\subsection{Physical Resources and the Implementation of Inclusive Education in Schools}

Provision of adequate and modified physical resources is important in order for learning institutions to remove barriers that make it difficult for learners with physical disabilities to move from one place to 
another. For successful inclusion of learners with physical challenges, there is need for establishing and accessing barrier free physical resources. The study sought to examine the teachers' perceptions on the effects of physical resources on the implementation of inclusive education in public secondary schools. The results were summarized in the Table 4

Table 4: Effects of physical resources and inclusion of learners with physical challenges

\begin{tabular}{|l|c|c|c|}
\hline & $\begin{array}{c}\text { Adequately } \\
\text { Done (\%) }\end{array}$ & $\begin{array}{c}\text { Moderately } \\
\text { Done (\%) }\end{array}$ & $\begin{array}{c}\text { Not done } \\
\text { at all (\%) }\end{array}$ \\
\hline $\begin{array}{l}\text { Mobility services and devises for learners with } \\
\text { physical challenges }\end{array}$ & 7.0 & 35.0 & 58.0 \\
\hline Equipping of resource rooms with modified furniture & 0.0 & 38.0 & 62.0 \\
\hline Modification of toilets/latrines for the PC students & 1.0 & 23.0 & 76.0 \\
\hline Modification of staircases into ramps in the school & 1.0 & 47.0 & 52.0 \\
\hline
\end{tabular}

According to the findings in Table 4, seven percent of teachers indicated that mobility services and standard devises were adequately provided while the $58 \%$ of the participants indicated that they were not provided at all. Further, $35 \%$ of the sampled teachers reported that mobility services for learners with physical disabilities were moderately provided. Further, from the data, $62 \%$ of the teachers indicated that resource rooms were not equipped with modified furniture for learners with physical disabilities while $38 \%$ indicated that such rooms are moderately equipped. None of the teachers reported that schools were adequately equipped resource rooms with modified furniture

The majority $(76 \%)$ teachers showed that schools had no modified toilets while $23 \%$ indicated that schools had moderately modified toilets for learners with physical disabilities. Only $1 \%$ of the sampled teachers indicated that schools had adequately modified toilets/latrines. Further, 52\% of teachers indicated that the schools had not modified staircases into ramps at all while $47 \%$ of the sampled teachers stated that staircases were moderately modified stairs into ramps in the schools. Only $1 \%$ of the respondent showed that the schools had adequately modified stairs into ramps.

\subsection{Regression Diagnostics}

Regression diagnostics involved testing linear regression model assumptions: Normality, Linearity, Homoscedasticity and Multicollinearity. For the linear regression model to be valid, there has to be an inherent linear relationship between independent and the dependent variables, the regression-standardized residuals have to be normally distributed, there should be constant variance of the standardized residuals along the corresponding predicted values and the independent variables should not be significantly correlated with each other. Prior to testing the four regression assumptions, the study removed outliers in order to remove extreme biased data. To remove the outliers, Mahalanobis distance, Centered Leverage distance and Cook's Distance statistics were used to look for extreme data. Using 'Select Cases' command in SPSS, the cases which had distance values above the aforementioned cutoff points were not selected for further linear regression analyses

The school practices as independent variables and the implementation of inclusive education as the dependent variables were subjected to the linear regression diagnostics. For normality test, the ShapiroWilk's, P-value $=0.027$, was less than $5 \%$ hence the data was not normally distributed. However, at $1 \%$ significance level, the data was normally distributed; the p-value of Shapiro-Wilk was 0.971. According to Ghasemi and Zahedias, (2012), a statistic approaching unity indicates sufficient normality in a data set for carrying out a linear regression assumption. For homoscedasticity, the observed p-values of Breusch-Pagan and Koenker were 0.315 and 0.213 respectively both greater than $5 \%$, hence no heteroscedasticity. For linearity, in ANOVA, the p-value was $0.000<0.05$ hence significant linear relationships between dependent and independent variables. Finally, for multicollinearity; the VIF value was $1.317<5$ and Tolerance was $0.760>0.5$ indicates lack of collinearity amongst the independent variables 
Table 5: Model Summary for Influence of Physical Resources and Implementation of Inclusive Education

\begin{tabular}{|r|r|r|r|}
\hline $\mathrm{R}$ & R Square & Adjusted R Square & Std. Error of the Estimate \\
\hline 0.351 & 0.123 & 0.086 & 3.53085 \\
\hline
\end{tabular}

Table 5, shows a moderate positive correlation between impact of physical resources and implementation of inclusive education with a correlation of 35.1 percent. The coefficient of determination (R Square) shows that 12.3 percent variations in implementation of inclusive education are due to variations in the resources.

Table 6: ANOVA for Physical Resources and Implementation of Inclusive Education

\begin{tabular}{|l|r|r|r|r|r|}
\hline Model & Sum of Squares & df & Mean Square & F & p-value \\
\hline Regression & 166.084 & 4 & 41.521 & 3.330 & 0.013 \\
\hline Residual & 1184.356 & 95 & 12.467 & & \\
\hline Total & 1350.440 & 99 & & & \\
\hline
\end{tabular}

Table 6 also shows that the p-value was 0.013 , less than 0.05 hence concluding that there was a significant linear relationship between physical resources and the implementation of inclusive education

Table 7: Regression Coefficients for Physical Resources and Implementation of Inclusive Education

\begin{tabular}{|c|c|c|c|c|c|c|c|}
\hline \multirow[t]{2}{*}{ Model } & \multicolumn{2}{|c|}{$\begin{array}{l}\text { Unstandardized } \\
\text { Coefficients }\end{array}$} & $\begin{array}{l}\text { Standardized } \\
\text { Coefficients }\end{array}$ & \multirow[t]{2}{*}{$\mathrm{t}$} & \multirow[t]{2}{*}{$\begin{array}{l}\mathrm{P}- \\
\text { value }\end{array}$} & \multicolumn{2}{|c|}{$\begin{array}{l}95.0 \% \text { Confidence } \\
\text { Interval for B }\end{array}$} \\
\hline & B & $\begin{array}{l}\text { Std. } \\
\text { Error }\end{array}$ & Beta & & & $\begin{array}{l}\text { Lower } \\
\text { Bound }\end{array}$ & $\begin{array}{l}\text { Upper } \\
\text { Bound }\end{array}$ \\
\hline (Constant) & 14.122 & 1.802 & & 7.839 & 0.000 & 10.547 & 17.697 \\
\hline Human resources & 0.365 & 0.104 & 0.335 & 3.518 & 0.013 & 0.159 & 0.570 \\
\hline
\end{tabular}

Table 7 shows the results from regression analysis where physical resources were the independent variable while implementation of inclusive education was the dependent variable. The unstandardized beta coefficient shows the increment of implementation of inclusive education with respect to the marginal increment in physical resources. The regression equation of the linear regression analysis is:

$$
\begin{array}{rcc}
\mathrm{Y}= & 14.122+ & 0.365 \mathrm{X} 1 \\
\mathrm{t}-\text { statistic } & 7.839 & 3.518 \\
\mathrm{p} \text {-value } & 0.000 & 0.013
\end{array}
$$

Where; Y - Dependent variable (Implementation of Inclusive Education)

$\mathrm{X}_{1}-$ School Resources

$\mathrm{e}-$ Regression error term

\section{Discussions}

From the study it was evident that mobility services and standardized devises were not provided at all in many of schools, which really impede mobility of learners with physical disabilities. The ability to discover and intermingle with the environment is critical and any inability to do so affects the person's psychologically, socially, emotionally and physically. Provision of a means of mobility to the learners with disabilities are known to improve their self-reliance, exploration, collaboration with the outer world and this result in improving learning opportunities (Heller, Forney, Alberto, Schawatzman \& Goeckel, 2000). Consistent with this, Coleman \& Heller, (2009), assert that when services and devices are not provided, students are left performing tasks less efficiently or less independently than their potential performance afforded by device use. To live an independent and dignified life within the society, learners with disabilities should have access to the standardized devices that facilitate their accessibility within the school environment 
The study established from a few interviewed learners that they struggle to walk with the type of mobility devices provided as they are made in unprofessional way. In the cause of the interviewing, the study found out that majority of the learners with disabilities came from poor family backgrounds and this hindered them from accessing good mobility devises. In affirmation, a research by DFID (2001) asserted that poverty and disability support each other. Disability often leads to segregation from education and employment chances, thereby causing economic drawback. The implication is that people with disabilities who get deprived of education cannot find employment in the public sector, driving them more deeply into poverty.

According to Kieran, et al, (1999), mobility services promote independence mainly by training in various motor skills such as walking, sitting, shifting position and balance. These services can efficiently be provided by the school if students have consistent physiotherapy with appropriate apparatus. Their fineness and efficacy can impact positively on academic participation and socialization of students with physical disabilities. According to News Digest (2007), the significance of mobility services include helping the students to restore the posture, walk and body alertness, monitor purposes and correct use of mobility devices. This implies that for the students to have sufficient school performance, a variety of mobility services should be provided to them. According to Hanson and Harris cited in Tassoni (2003), when coming up with such approaches for independent mobility, the goals should include: assisting the student to start interaction with and control various features of his environment. The implication is that the services and devices help the learners with physical disabilities to acquire mobility skills, which enables them to acquire and gain self-help skills from mobility trainings.

The study also revealed that majority $(76 \%)$ of teachers felt that many schools lacks modified toilets hence learners with disabilities use the general toilets used by non-disabled learners. This poses a real danger and unhealthy hazard. Berhanu \& Gebremedhin, (2016) affirmed that latrine access is one of the challenges facing by students with physical disabilities that limit their mobility whether at home or in schools. They suggest that latrines should be designed, constructed and situated such that they are easily accessible and utilizable. According to UNICEF, (2008), the design for latrines in schools should be redesigned to ensure improved accessibility for children with disabilities. The schools should ensure that the latrines are more user-friendly and spacious for all the learners, especially those with physical disabilities

From the data, many schools have not modified their staircases into ramps. This implies that several buildings are inaccessible or they pose a real danger to learners with physical disabilities when accessing them. This was attested to by a form four student who has an artificial lower limb. The student had a bad experience when he was in the lower classes. He shared the following traumatizing experience

"I was climbing down from the school library located in the second floor when I slipped off a steep staircase. I lost balance and fell dangerously. My prosthesis which is connected at the knee got dislodged. As I tried to stand up with the help of handrails I felt some sharp pain near the ankle of the other leg. The other students carried me to the school nurse. Upon examination, the normal leg had a small crack. I became frustrated and contemplated discontinuing with the school. That marked the end of attending library classes until I completed the school".

Such traumatizing real experiences made the student very depressed and vulnerable. One focus group shared on how some students dropped out of school, while others were withdrawn by their parents who felt that the school was not prepared to cater for needs of their children. Feeling of powerlessness may come into play when such students feel that there is nothing they can do to change the situation of their vulnerable colleagues

A disability is only disabling when it prevents learners from doing what they want or need to do. UNICEF, (2012) asserts that poorly designed physical environments exclude persons with disabilities from participating in mainstream society. Nasarwanji (2008) reinforce this notion by affirming that stairways into buildings have been reported amongst the most challenging environmental barriers for users of wheeled mobility devices. The implication of this is that students with physical disabilities continue to encounter physical barriers to educational services, due to lack of ramps and elevators to access key resource rooms in 
schools, heavy doors, inaccessible washrooms, and inaccessible transportation to and from school. Lack support systems for students with disabilities discussed above are critical to the implementation of inclusive education.

Accessing buildings through ramps are especially important as learners with physical disabilities especially those with wheelchairs and scooters cannot manage move through the stairs. People with walkers, canes, and crutches may also find that ramps are easier to access buildings than staircases. In Kenya, the Persons with Disability Act of 2003 require public buildings to be retrofitted with ramps to ease access to services offered therein to persons with physical disability and the elderly. According to the Kenya Constitution (2010) part 3 , subsections 54, individuals with any disability are entitled to access any facilities that are integrated into the society to get services wanted. The implication is that all students have the opportunity to be actively involved in the life of their school and in the wider community. However, many students with physical disabilities face barriers in the school. As a result, they may lack confidence and feel different to their peers and out of place at times. It is the role of the teachers to adapt tasks in the classroom setting for all students to participate and contribute. The teachers ought to create opportunities for students with special education needs to build friendships and to develop a positive self-esteem.

\section{Conclusion}

Physical resources can pose as a barrier to learners with disability and can limit their personal mobility. It is evident from the study that schools have not effectively been able to remove physical barriers that facilitate learners with physical disabilities to access and participate fully in their learning process. Modified physical resources are crucial for learners with physical disability. By creating supportive learning environments, will not only uplift the learners' self-esteem but also improve the academic performance

\section{Recommendations}

1. Mobile devises are not cheap to learners who hail from poor family backgrounds. The school should involve a broad range of stakeholders who would be willing to provide mobility devises. This can be done by developing a strong partnership among stakeholders to provide support to learners with physical disabilities who may not afford such devices

2. Physical resources should be audited by trained Barrier Free Auditors. The Auditing should take into account all buildings including student accommodation, resource rooms such as science laboratories, computer labs, classrooms and libraries, spiritual and recreational facilities Schools should use such audit reports to restructure the physical environment for all learners

3. The Government should supervise all the physical resources to ensure that they are barrier free for all learners. It should also set aside some funds for those schools that have enrolled learners with physical disabilities to restructure and modify the physical environment

\section{References}

[1] Abimanyi-Ochom, J. \& Mannan, H., 2014, „Uganda“es disability journey: Progress and challenges African Journal of Disability 3(1), Art. \#108, 6 pages. http://dx.doi.org/10.4102/ajod.v3i1.108

[2] Agarwal, A. \& Chakravarti, D. (2014) Universal Accessibility Guidelines for Pedestrian, nonmotorized Vehicles and Public Transport Infrastructure. New Delhi: SSEF. Available http://shaktifoundation.in/wp-content/uploads/2014/02/

[3] Adoyo, P.O. \& Odeny, M.L. (2015). Emergent inclusive Education Practice in Kenya: Challenges and suggestions. International Journal of Research in Humanities and Social $\quad$ Studies 2 (6) 4752.

[4] Agius Ferrante, Charmaine (2012) A case study of inclusion and diversity: a whole school approach using the social model of disability. Doctoral thesis, Northumbria University. This version was downloaded from Northumbria Research Link: http://nrl.northumbria.ac.uk/8772/

[5] Ainscow, M. and Sandill, A. (2010). Developing inclusive education systems: the role of organisational cultures and leadership. International Journal of Inclusive Education, 14 (4): 401416 
[6] Ainscow, M. (2005). Developing inclusive education systems: what are the levers for change? Journal of Educational Change, 6(2), 109- 124

[7] Ainscow, M., Booth, T. and Dyson, A. (2004) Understanding and developing inclusive practices in schools: a collaborative action research network, International Journal of Inclusive Education, 8(2), pp.125-139.

[8] Althaus, C., Bridgman, P., \& Davies, G. (2007). The Australian policy handbook. Crows Nest, NSW: Allen \& Unwin.

[9] Allan, J. (2008). Rethinking inclusive education. Dordrecht: Springer.

[10] Anastasiou, D. \& Kauffman, J. (2012): Disability as cultural difference: Implications for special education. In: Remedial and Special Education, 33, pp. 139-149

[11] Apple, M. (2004). Ideology \& curriculum. London: RoutledgeFalmer.

[12] Asmus, R; Hussel, B; Asmus, Harald; Rick, Johannes J; Wiltshire, Karen H .(2017). Gelatinous zooplankton abundance at Sylt Roads - Wadden Sea off List, Sylt, North Sea in 2010. Alfred Wegener Institute - Wadden Sea Station Sylt, PANGAEA, https://doi.org/10.1594/PANGAEA.880600

[13] Bagree, S and Myers, J .(2011). Making Inclusive Education a Reality, Sightsavers policy paper, hwww.sightsavers.org/indepth/policyandresearch/education/16079_Sightsavers\%20IE\%20Policy\%2 0Paper\%202011\%20-\%20FINAL.pdf.

[14] Beatriz P., Deborah N., Hunter M. (2008). Improving school leadership volume 1: policy and practice. Paris: OECD; www.oecd.org/publishing/corrigenda

[15] Boer, A., Pijl, S. J., \& Minnaert, A. (2011). Regular primary schoolteachers ${ }^{\text {ee }}$ attitudes towards inclusive education: A review of the literature. International Journal of Inclusive Education, 15(3), 331-353.

[16] Budlender, D. (2015). Budgeting for Realising the Right to Basic Education for Children with Disabilities in South Africa, Annexure to SECTION 27, Left in the Dark. Amazon .aws.com/160308 left in the dark annexure C.pdf.

[17] Clayton, P. H., Bringle, R. G., Senor, B., Huq, J., \& Morrison, M. (2010). Differentiating and assessing relationships in service-learning and civic engagement: Exploitive, transactional, and transformational. Michigan Journal of Community Service Learning, 16(2), 5-21.

[18] Creswell, J. W., \& Plano Clark, V.L. (2011). Designing and conducting mixed methods research (2nd ed.). Thousand Oaks, CA: Sage Publications, Inc

[19] Carter, E.W. \& Hughes, C. (2005). Increasing social interaction among adolescents with intellectual disabilities and their general education peers: effective interventions. Research \& Practice for Persons with Severe Disabilities, 30(4), 179-193

[20] Chataika, T., Mckenzie, J., Swart, E. \& Lyner-Cleophas, M., (2012). 'Access to Education in Africa: Responding to the United Nations Convention on the Rights of Persons with disabilities', Disability and Society 27(3), 385-398

Chiner \& Cardina C (2012).Inclusive education in Spain: how do skills, resources, and supports affect regular education teachers' perceptions of inclusion? https://www.tandfonline.com/doi/abs/10.1080/13603116.2012.689864

[21] Cohen R, Swerdlik M. (2010). Psychological testing and assessment. Boston: McGraw-Hill Higher Education; [Google Scholar]

[22] Cook, A. M., \& Polgar, J. M. (2015). Assistive Technologies: Principles and practice, 4th ed. St. Louis, MO, USA: Elsevier Inc.

[23] DFID (2001) Disability, Poverty and Development, Department for International Development, London

[24] Drudy, S. \& Kinsella, W. (2009). "Developing an Inclusive System in a Rapidly Changing European Society." International Journal of Inclusive Education, 13(6): 647-663.

[25] Emanuelsson, I., Haug, P. and Persson, B. (2005). Inclusive education in some Western European countries: different policy rhetorics and school realities, in D. Mitchell (Ed.). Contextualizing inclusive education evaluating old and new international perspectives. London: Routledge, pp. 114-138

[26] Frattura, E. M. and Capper, C. A., (2007). Leading for Social Justice: Transforming Schools for all learners. Thousand Oaks, CA: Corwin Press 
[27] Forlin, C. ( 2005). Implementing an outcomes-focussed approach to learning: Implications inclusive education. Centre for Advancement of Special Education, 1, 3-6

[28] Gall, M. D., Gall, J. P., \& Borg, W. R. (2006). Educational research: an introduction. Boston, Mass: Pearson

[29] Ghasemi, A., Zahediasl, S. (2012). Normality Tests for Statistical Analysis: A Guide for NonStatisticians, International Journal of Endocrinology and Metabolism, 10(2):486- 489. DOI: 10.5812/ijem.3505

[30] Government of Kenya. (2005). Kenya Education Sector Support Programme (KESSP, 2005 - 2010) 'Delivering Quality Education and Training to all Kenyans'. Nairobi, Kenya, Government Printers

[31] Government of Kenya. (2005). Sessional Paper No: 1 of 2005 on policy framework for Educational, Training and Research. Nairobi: Government Printer.

[32] Government of Kenya. (2007). Kenya Vision 2030: A Globally Competitive and Prosperous Kenya. Nairobi: Government Printer.

[33] Government of Kenya. (2008). Kenya national survey for persons with disability. Nairobi: Government Printers.

[34] Government of Kenya. (2009). National Special Education Policy Framework. Nairobi: Government Printers.

[35] Government of Kenya. (2010). The Constitution of Kenya. Nairobi: Government Printer

[36] Heller, W.K.; Forney, P.E, Alberto, P.A.; Schartzman, M.N., \& Goeckel, T.M. (2000). Meeting Physical and Health Needs of Children with Disabilities: Teaching Student Participation and Management. Toronto: Wadsworth-Thomson-Learning.

[37] Howgego, C. Miles, S. \& Myers, J. (2014). Inclusive Learning Children with disabilities difficulties in learning. http://www.eenet.org.uk/.../InclusiveLearningTopicGuide-final.pd.

[38] Jackie Mader. (2017). Strong progress has been made to integrate students with disabilities into general-education classrooms. Educator instruction hasn't kept up. https://www.theatlantic.com/.../03/...teacher-training...special-needs-students/518286/

[39] Jerald, C. D. (2006). Issue Brief. School Culture: "The Hidden Curriculum." Washington, DC: The Center for Comprehensive School Reform and Improvement. http://www.centerforcsri.org

[40] Jeffrey, J. M. (2013). Benefits and barriers to physical activity for individuals with disabilities: a social-related model of disability perspective, Wayne State University, Detroit, MI, USA

[41] Jooyeon, J., Joonkoo, Y. \& Stamatis, A. (2017). Impact of enjoyment on physical activity health among children with disabilities in schools. https://doi.org/10.1016/j.dhjo.2017.04.004

[42] Johnson, R. B., Onwuegbuzie, A. J., \& Turner, L. A. (2007). Toward a definition of mixed methods research. Journal of Mixed Methods Research, 1(2),112-113.

[43] Kalyanpur, M. (2014). Distortions and dichotomies in inclusive education for children with disabilities in Cambodia in the context of globalisation and international development. International Journal of Disability, Development and Education, 61(1), 80-94

[44] KNCHR .(2007). Objects of pity or individuals with rights: The right to education for children with disabilities. Nairobi: Kenya National Commission on Human Rights.

[45] Kieran, S. S., Connor, F.P, Hippel V.S.C., \& Jones H.S (1999). Pre-schools: Children with Orthopedic Handicapping. Washington D.C: Dhew Publication

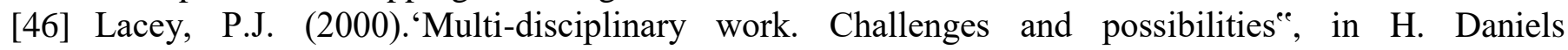
(Ed.),Special education re- - formed: Beyond rhetoric .London: Falmer

[47] Lai, M. C., Lombardo, M. V., Auyeung, B. (2015). Sex/gender differences and autism: scene for future research. Journal of the American Academy of Child and Adolescent 54(1): 11-24. [PMC free article] [PubMed] [Google Scholar]

setting the Psychiatry

[48] Lynch, P et al,. (2011). 'Inclusive educational practices in Uganda: evidencing practice of itinerant teachers who work with children with visual impairment in local mainstream schools ${ }^{\text {ee }}$, International Journal of Inclusive Education, 15(10): 1119-34.

[49] McMillan, J. H \& Schumacher, S. (2006). Research in Education: a conceptual introduction. 5th edition. New York. Longman.

[50] McMillan, J. H \& Schumacher, S. (2001). Research in Education: a conceptual introduction. 5th edition. New York. Longman. 
[51] McCurdy, E.E. \& Cole, C.L. (2014). Use of a peer support intervention for promoting academicengagement of students with autism in general education settings. Journals of Autism and Developmental Disorders, 44(4), 883-893. https://doi:10.1007\%2Fs10803-013-1941-5

[52] Mitchell D. (2005). Introduction; sixteen propositions on the contexts of inclusive education, evaluating old and new international perspectives. London: Routledge, pp. 230-252

[53] Mitchell, D. (2006). Making inclusive education work: Learning from experience. Paper presented at the meeting of the Western Cape Department of Education on Inclusive Education. Cape Town, South Africa

[54] Mitchell, D. (2015). Inclusive education is a multi-faceted concept. Center for Educational Policy Studies Journal (Slovenia), 5(1), 9-30.

[55] Mertens, D. M., \& McLaughlin, J. A. (2004). Research and evaluation methods in special education. Thousand Oaks, Calif: Corwin Press.

[56] Mugenda, O.M. and Mugenda, A.G. (1999). Research Methods: Quantitative and Qualitative Approaches. Acts Press, Nairobi.

[57] Mulugeta, Y. (2015). Effectiveness of primary school principals in managing the implementation of civic and ethical education curriculum BJE, 15 (1) (2015), pp. 24-40

[58] Mutembei, R. (2014). School factors influencing implementation of inclusive education in public primary schools in Magumoni division, Tharaka nithi county, Unpublished MED Thesis University of Nairobi, Nairobi, Kenya.

[59] Mukhopadhyay, S. (2015). West is best? A post-colonial perspective on the implementation of education in Botswana. KEDI Journal of Educational Policy, 12(1), 19-39

[60] Nassiuma, D. K. \& Mwangi, J. W. (2004). Statistical methods for Information Analysis: An Introduction. Egerton University Press.

[61] News Digest: (2007). Related Services . http://www.nichcy. Org/pubs/ news dig/ nd16 text. Htm. Accessed November, 2007

[62] Njoka, E., Riechi, A., Obiero, C., Kemunto, E., Muraya, D., Ongoto, J., \& Amenya, D. (2012). Towards inclusive and equitable basic education system: Kenya's experience. (ADEA), held on February

[63] Nungu, M. (2010). Universalizing Access to Primary Education in Kenya: Myths and Realities', Canadian Journal for New Scholars in Education Vol.3 (2) pp1- 15

[64] Ojiambo, P. O., (2009). Quality of Education and its Role in National Development: A Case Study of Kenya's Educational Reforms. Kenya Studies Review: 1(1), 133-149.

[65] Puhan,.R.. Malla, L. Behera S. (2014). Current ethical issues in teacher education: a critical analysis on pre-service and in-service emerging teachers Am. J. Educ. Res., 2 (12A) (2014), pp. 1-7

[66] Republic of Kenya. (2012). A policy Framework for Kenya. Aligning Education and Training to the Constitution of Kenya (2010) and Kenya Vision 2030 and beyond. Nairobi: Government printers

[67] Republic of Kenya. (2013). Education Act Kenya: The Basic Education Act, 2013. Nairobi: Government Printer

[68] Republic of Kenya. (2010). A Task Force on Realignment of Education System to the Constitution of Kenya. Nairobi: MoE.

[69] Republic of Kenya. (2017). Basic Education Curriculum Framework. Kenya Institute of Curriculum Development, Nairobi, Government Printers

[70] Rickert, T. (2010). Bus rapid transit accessibility guidelines. Washington, D. C.: World Bank.Available at: http://siteresources.worldbank.org/DISABILITY/Resources/280658$1172672474385 /$ BusRapidEngRickert.pdf

[71] Sæbønes, A. M. (2015). Toward a Disability Inclusive Education: Background Paper for the Oslo Summit on Education for Development. World Health Organization (2011). World Report on Disability.

[72] Save the Children (2000) Making Inclusive Possible: How can change happen Save the Children's experience, London,

[73] Stofile, S. (2008). Factors affecting the implementation of inclusive education in policy: (Unpublished Doctorate). University of the Western Cape.: 
[74] Tassoni, P. (2003). Professional Development: Supporting Special Needs: Understanding Inclusion in Early Years. London: Heinemann.

[75] Tesfaye, S. Bohl, T.. Kleinknecht.M .(2013). Civic education in Ethiopian schools: adopted paradigms, instructional technology, and democratic citizenship in a multicultural context Int. J. Educ. Dev., 33 (2013), pp. 156-164

[76] UNESCO .(1994). The Salamanca Statement and Framework for Action on Special Needs Education [online]. Available at: http://www.unesco.org/education/pdf/SALAMA_E.PDF [Accessed 16 March 2012]

[77] UNESCO. (2000). The Dakar Framework for Action [online]. Available at: http://unesdoc.unesco.org/images/0012/001211/121147e.pdf [Accessed 27 June 2014]

[78] UNESCO. (2005). Challenges of Implementing Free Primary Education in Kenya: Assessment Report. Nairobi: UNESCO.

[79] UNESCO, (2015). A guide for ensuring inclusion and equity in education. Paris, France Open Access Repository (http://www.unesco.org/open-access/terms-use-ccbysa-en).

[80] Waldron, N., McLeskey, J., \& Redd, L. (2011). Setting the direction: The role of the principal in developing an effective, inclusive school. Journal of Special Education Leadership, 24, 51-60.

[81] Watkins, A. (2007). Assessment in Inclusive Settings: Key Issues for Policy and Practice. Odense, Denmark: European Agency for Development in Special Needs Education. http://www.europeanagency.org/publications/ereports/assessment-ininclusive-settings

[82] Weber, M., and Ruch, W.(2012). The role of a good character in 12-year-ld school children: do character strengths matter in the classroom? Child Indic. Res. 5, 317- 334. doi:10.1007/s12187011- 9128-0

[83] Winzer, M., Mazurek, K. (2017). The Convention on the Rights of Persons with Disabilities: Reconstructing disability to reimagine education. In: M. Hughes \& E. Talbott (Eds.): Handbook of research on diversity in special education, (pp. 1-19). New York:John Wiley 